\title{
Seed-transmitted beneficial endophytic Stagonospora sp. can penetrate the walls of the root epidermis, but does not proliferate in the cortex, of Phragmites australis
}

\author{
Kexiang Gao and Kurt Mendgen
}

\begin{abstract}
Stagonospora sp. (4/99-1) is a beneficial endophytic fungus frequently transmitted by seeds of Phragmites australis [Cav.] Trin. ex Steudel. Here we show that this fungus also penetrates the root epidermis. At first, hyphae were attracted by the root and proliferated on the root surface, preferably over the anticlinal walls. Penetration occurred directly by undifferentiated hyphae or was facilitated by hyphopodia. Hyphal growth within the root was restricted to the walls of epidermal cells and the walls of the cells of the outermost cortical layer. Deeper growth by the fungus elicited wall appositions and ingress into the cytoplasm of cortical cells was blocked by papillae. In the rare cases, the fungus managed to penetrate into cortical cells, these reacted with necrosis. Immunological studies suggested that fungal material reached the host plasmalemma and may have been taken up by endocytotic events. Our observations explain the endophytic lifestyle of hyphae close to the epidermis and the restricted development within the cortex.
\end{abstract}

Key words: Stagonospora, Phragmites australis, infection, root cortex, root epidermis.

Résumé : Le Stagonospora sp. (4/99-1) est un champignon endophyte bénéfique, très souvent transmis par les semences du Phragmitis australis [Cav.] Trin. ex Steudel. On démontre ici que ce champignon pénètre également l'épiderme racinaire. Au départ, les hyphes sont attirées par la racine et prolifèrent sur la surface racinaire, préférablement sur les parois anticlines. La pénétration s'effectue directement par des hyphes indifférenciées, ou est facilitée par un hyphopode. La croissance de l'hyphe dans la racine est limitée aux parois des cellules épidermiques et de la couche corticale la plus externe. Une croissance plus en profondeur du champignon élicite des appositions pariétales et la pénétration dans le cytoplasme des cellules corticales est bloquée par des papilles. Dans les rares cas où le champignon s'est infiltré jusque dans les cellules corticales, celles-ci ont réagi avec une nécrose. Des essais immunologiques suggèrent que le matériel fongique atteint la plasmalemme de l'hôte, et pourrait été impliqué dans des évènement endocytotiques. Ces observations expliquent le mode de vie endophyte des hyphes à proximité de l'épiderme et le développement restreint dans le cortex.

Mots clés : Stagonospora, Phragmites australis, infection, cortex racinaire, épiderme racinaire.

[Traduit par la Rédaction]

\section{Introduction}

Endophytic fungi can colonize plants without causing the apparent negative effects typical of plant pathogenic fungi (Jumpponen and Trappe 1998; Schulz and Boyle 2005). Especially in mutualistic associations, the benign way to proliferate within plant organs is very different from proliferation in pathogenic associations (Schardl et al. 2004). This difference may become obvious during the early stages of fungal penetration and infection.

Leaf endophytes, such as Discula umbrinella, penetrate

Received 2 December 2005. Published on the NRC Research Press Web site at http://canjbot.nrc.ca on 3 August 2006.

K. Gao. ${ }^{1}$ Northwest Sci-Tech University of Agriculture and Forestry, Yangling, Shaanxi 712100, P.R. China.

K. Mendgen. ${ }^{2}$ Phytopathology, Department of Biology,

University of Konstanz, D-78457 Konstanz, Germany.

${ }^{1}$ Present address: Department of Plant Pathology, Shandong Agricultural University, Taian 271018, P.R. China.

${ }^{2}$ Corresponding author (e-mail:

Kurt.W.Mendgen@uni-konstanz.de). the epidermis of Fagus sylvatica (beech) leaves directly or with appressorium-like structures and differentiate only short subcuticular or subepidermal hyphae similar to hemitrophic or biotrophic fungi (Viret and Petrini 1994). Gloeosporium platani, a close relative of $D$. umbrinella, terminates infection soon after differentiation of the appressorium (Seifers and Ammon 1980). The endophytic Rhabdocline parkeri also penetrates Pseudotsuga menziesii (Douglas-fir) needles using an appressorium, but infection is restricted to single cells and intracellular hyphae proliferate only at the onset of needle senescence (Stone 1988). In addition to direct penetration of the cuticle, stomatal penetration by barely differentiated hyphae is also observed in several endophytes of Juncus species. Here, infection is restricted to the substomatal chambers and only very little intercellular colonization occurs (Cabral et al. 1993). It seems that in these endophytic fungi, the modes of early plant leaf infection are very similar to those of plant pathogenic fungi (Tucker and Talbot 2001), but proliferation of hyphae is very much restricted.

On the other hand, some endophytic fungi may not need infection structures for host invasion. For example, species of Neotyphodium inhabit many Pooideae grasses and form 
Fig. 1. Two hyphae of Stagonospora sp. strain 4/99-1 that originated from an agar plug and grew toward a reed (Phragmites australis) root $2 \mathrm{~mm}$ away. (LM, scale bar $=20 \mu \mathrm{m}$.) Fig. 2. Hyphae growing along the anticlinal walls of epidermal cells. Hyphopodia are evident at the arrows. (LTSEM, scale bar $=2 \mu \mathrm{m}$.) Fig. 3. A hyphal branch that has penetrated the host epidermis without obvious signs of cuticle degradation. (LTSEM, scale bar $=1 \mu \mathrm{m}$.) Fig. 4. Example of intercellular penetration resulting from a hypha pushing epidermal cells (e) apart. (LTSEM, scale bar $=1 \mu \mathrm{m}$.) Fig. 5. Cross section of a hypha growing within the walls of two adjoining epidermal cells. e, epidermal cell; h, hypha; cu, cuticle. (TEM, scale bar $=1 \mu \mathrm{m}$.) Fig. 6. The wall of a cortical cell, close to an endophytic hypha. The plasmalemma exhibits extensive bulges (arrows). A vesicle with translucent contents (arrowhead) is evident in the host cell cytoplasm. (TEM, scale bar $=0.5 \mu \mathrm{m}$.) Fig. 7. Advanced stage of vesicle production in the wall of a cortical cell, close to an endophytic hypha: Vesicle contents are electron dense (arrows). (TEM, scale bar $=0.5 \mu \mathrm{m}$.)

intimate relationships with the plants. These asexual endophytes are mostly biotrophic and some seem to disseminate only by infected seeds (Schardl and Phillips 1997). Growth of hyphae occurs throughout the stem and appears to be highly regulated. Apical extension and branching of hyphae ceases when culm or leaf growth is complete (Christensen et al. 2002). Infection from the outside of the plant is difficult and may even require wounding (Latch and Christensen 1985).

The endophyte Stagonospora sp. strain 4/99-1 enhances growth and biomass of seedlings of the reed Phragmites australis (Ernst et al. 2003). Hyphae proliferate within all organs of the plant, but in only approximately $30 \%$ of the seeds (Ernst et al. 2003). In addition to seed transmission, young, fungus-free seedlings become reinfected after being planted in Stagonospora-infected soil (Ernst et al. 2003). Therefore, we investigated, using electron microscopy, how this endophyte penetrates and colonizes roots. To understand the beneficial growth of hyphae within host tissue, we looked for factors that may regulate the interaction between fungus and plant. We wanted to explain the contrast between pathogenic qualities, such as penetration and restricted proliferation, which may be prerequisites for the beneficial influence on the development of the host plant.

\section{Materials and methods}

\section{Plant and fungal material}

Seeds of Phragmites australis [Cav.] Trin. ex Steudel (Jelitto Staudensamen GmbH, Schwarmstedt, Germany), were treated with $70 \%$ ethanol (5 min), $5 \%$ sodium hypochlorite (5 min) and, again, $70 \%$ ethanol (5 min). After four final rinses $(10 \mathrm{~min})$ in sterile deionized water, seeds were placed on MS medium (Murashinge and Skoog 1962). After germination, plants were cultivated in a growth chamber adjusted to a $16 \mathrm{~h}$ cycle of light at $24{ }^{\circ} \mathrm{C}$ and $8 \mathrm{~h}$ of darkness at $20{ }^{\circ} \mathrm{C}$. Regular white light was used for illumination (Osram L58W/25 Universal-White, Munich, Germany).

Stagonospora sp. strain 4/99-1 had been isolated previously from seeds of the reed and was cultivated as described by Ernst et al. (2003).

\section{Inoculation}

For light microscopy, seedlings (4 weeks old) with 1$2 \mathrm{~cm}$ long roots were transferred onto slides with a thin layer of $1 \%$ water agar. Fresh agar plugs with Stagonospora sp. strain 4/99-1 were placed at a distance of 1, 2, 4, and $8 \mathrm{~mm}$ from the roots. To keep air humidity saturated, samples were kept on wet filter paper in Petri dishes at $20{ }^{\circ} \mathrm{C}$ in the dark. For electron microscopy, root samples with the agar plugs at a distance of $2 \mathrm{~mm}$ from the roots were examined.

\section{Light microscopy (LM)}

Growth of hyphae and infection of plant roots was followed 1, 2, 3, 4, and $5 \mathrm{~d}$ after inoculation with a Zeiss Axioskop microscope (Zeiss, Jena, Germany) equipped with Plan-Neofluar 10×, 40×, and 63× lenses (Zeiss, Jena, Germany) using phase contrast or DIC interference contrast.

\section{Low-temperature scanning electron microscopy (LTSEM)}

Two d after inoculation, 10 root samples were mounted on aluminium stubs with Tissue-tec (Sakura, Tokyo, Japan) and frozen by plunging the sample into nitrogen slush. After the removal of ice deposits, samples were coated with $6 \mathrm{~nm}$ platinum within the Alto 2500 (Gatan, Oxford, UK) preparation chamber and subsequently mounted onto the cryostage cooled to $-125{ }^{\circ} \mathrm{C}$. Observation was performed with a S4700 field emission scanning electron microscope (Hitachi, Tokyo, Japan) running in the normal mode. SEM micrographs were recorded digitally at an acceleration voltage of $2 \mathrm{kV}$.

\section{Transmission electron microscopy (TEM)}

Root samples were fixed at $24 \mathrm{~h}$ as well as 2, 3, 4, and $5 \mathrm{~d}$ after inoculation by immersion of $10 \mathrm{~mm}$ long root pieces in $2 \%(\mathrm{v} / \mathrm{v})$ glutaraldehyde in $0.1 \mathrm{~mol} / \mathrm{L}$ cacodylate buffer ( $\mathrm{pH} 7.4$ ) with $1 \mathrm{mmol} / \mathrm{L} \mathrm{CaCl}_{2}$ and $1 \%(\mathrm{~m} / \mathrm{v})$ sucrose for $3 \mathrm{~h}$ at room temperature. Samples were rinsed six times in $0.1 \mathrm{~mol} / \mathrm{L}$ cacodylate buffer $(\mathrm{pH} 7.4)$ with $1 \mathrm{mmol} / \mathrm{L}$ $\mathrm{CaCl}_{2}$ and $1 \%(\mathrm{~m} / \mathrm{v})$ sucrose and post-fixed with $1 \%(\mathrm{~m} / \mathrm{v})$ osmium tetroxide in the same buffer for $2 \mathrm{~h}$ at room temperature. Samples were rinsed thoroughly with $0.1 \mathrm{~mol} / \mathrm{L}$ cacodylate buffer $(\mathrm{pH}$ 7.4) and then dehydrated in a graded ethanol series. Fully dehydrated samples were moved from absolute ethanol through a 1:1 mixture of ethanol and propylene oxide to pure propylene oxide and then infiltrated with an Epon-Araldit mixture with propylene oxide (1:1) and embedded in moulds with fresh $100 \%$ resin. Samples were polymerized at $65{ }^{\circ} \mathrm{C}$ for $36 \mathrm{~h}$. Ultrathin sections, cut with a glass knife, were transferred onto formvar coated slot grids. After drying, the grids were stained with uranyl acetate $(30 \mathrm{~min})$ and lead citrate $(3 \mathrm{~min})$ and examined with an EM 10 CR electron microscope (Zeiss, Oberkochen, Germany) at $60 \mathrm{kV}$. Each sampling time consisted of five variants. From each variant, 20-60 sections were studied.

\section{Immunogold labelling}

Polyclonal antisera were prepared against mycelia of 

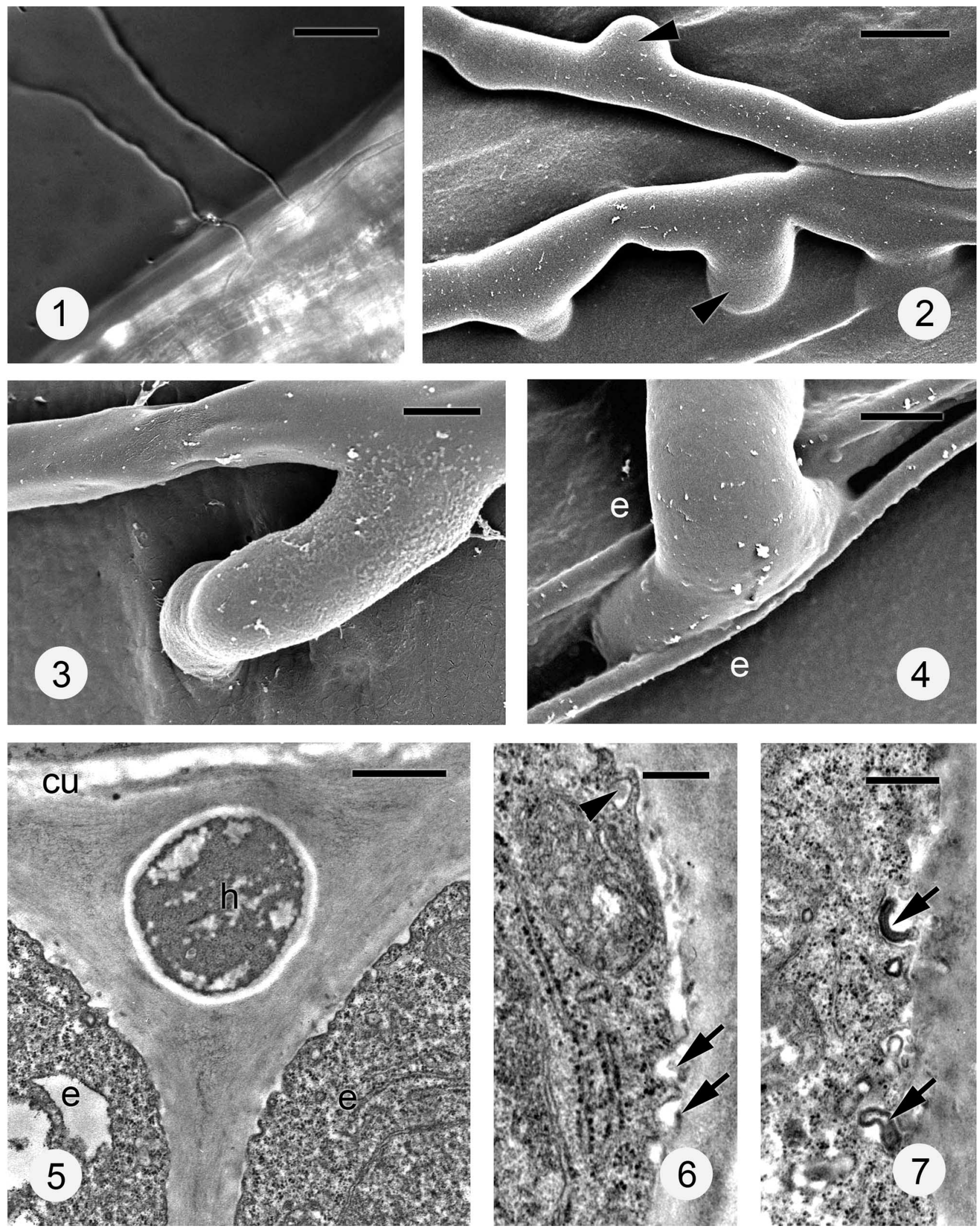

strain 4/99-1 that had been washed with sterile distilled water, dried, frozen in liquid nitrogen, and pulverized. A New Zealand white rabbit was immunized with $5 \mathrm{mg}$ of this powder together with $500 \mu \mathrm{L}$ of complete Freund adjuvant biweekly, four times.

To eliminate unspecific interactions of the antiserum with the plant tissue, sterile reed roots (Ernst et al. 2003) were frozen in liquid nitrogen and pulverized. Ten grams of this powder were added to an equal volume of Tris-buffered saline (TBS, $10 \mathrm{mmol} / \mathrm{L}$ Tris- $\mathrm{HCl}, 150 \mathrm{mmol} / \mathrm{L} \mathrm{NaCl}, \mathrm{pH}$ 7.4), 
Fig. 8. A hypha (h) of Stagonospora sp. strain 4/99-1 growing between two reed (Phragmites australis) cortical cells 4 d after inoculation. Prominent wall appositions (wa) encase the hypha. (TEM, scale bar $=0.5 \mu \mathrm{m}$.) Fig. 9. Immunogold labelling of fungal hyphae $3 \mathrm{~d}$ after inoculation. The label was most dense over fungal hyphae (h). In addition, it extended far into the host cell walls. e, epidermal cell; c, cortical cell. (TEM, scale bar $=1 \mu \mathrm{m}$.) Fig. 10. Example of labelling very close to the plant cell plasma membrane (arrow heads) and also within a vesicle in the plant cytoplasm (arrow). h, hypha; pc, plant cytoplasm. (TEM, scale bar $=0.5 \mu \mathrm{m}$.) Fig. 11. Control section of infected plant tissue incubated with the preimmune serum and the secondary antibodies coupled to $10 \mathrm{~nm}$ gold. (TEM, scale bar $=1 \mu \mathrm{m}$.)

Fig. 12. Control section of root epidermal cells incubated with the serum after immunization. This serum was treated with plant extracts and the secondary antibodies coupled to $10 \mathrm{~nm}$ gold. (TEM, scale bar $=1 \mu \mathrm{m}$.)
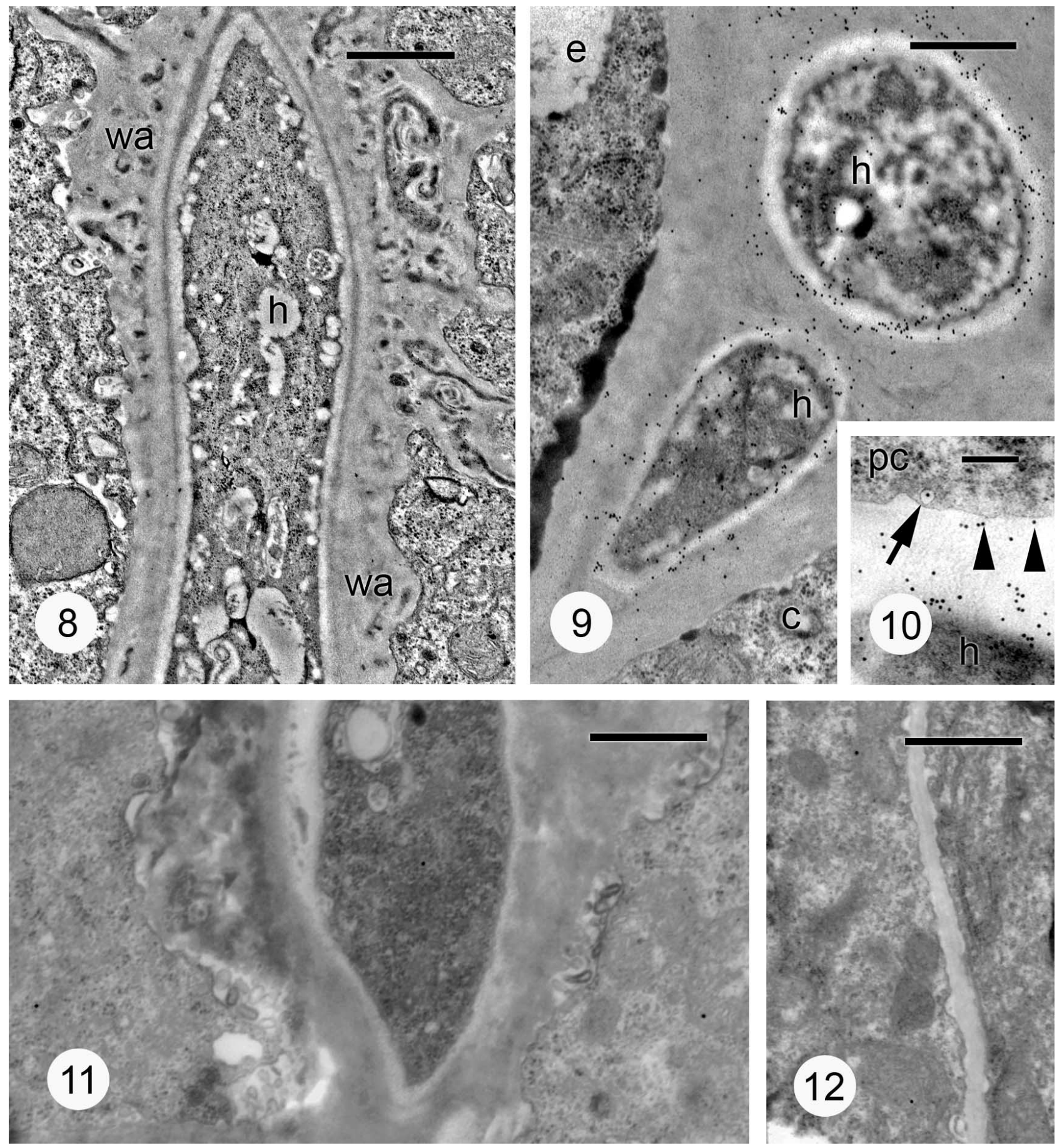

sonicated for $5 \mathrm{~min}$ (Branson Sonifier 250, SchwaebischGmuend, Germany), and autoclaved. One volume of the serum was mixed with half a volume of TBS and half a volume of the plant extract and incubated for $3 \mathrm{~h}$ at ambient temperature. The mixture was purified by centrifugation for $10 \mathrm{~min}$ at $23100 \mathrm{~g}$ and the supernatant was used for labelling.

Immunogold labelling was carried out by etching ultrathin 
Fig. 13. Apparent attempted penetration by the endophytic fungus (Stagonospora sp. strain 4/99-1) into the cortical cell wall of the reed (Phragmites australis). A prominent papilla (p) is obvious. h, hypha; c, cortical cell. (TEM, scale bar $=1 \mu \mathrm{m}$.) Fig. 14. Epidermal cell (e) and dead cortical cell (c). Some hyphae (h) exhibiting intact cytoplasmic contents are visible within the necrotized cortical cell. Apparently these hyphae did not proliferate deeper into the plant tissue. (TEM, scale bar $=1 \mu \mathrm{m}$.)

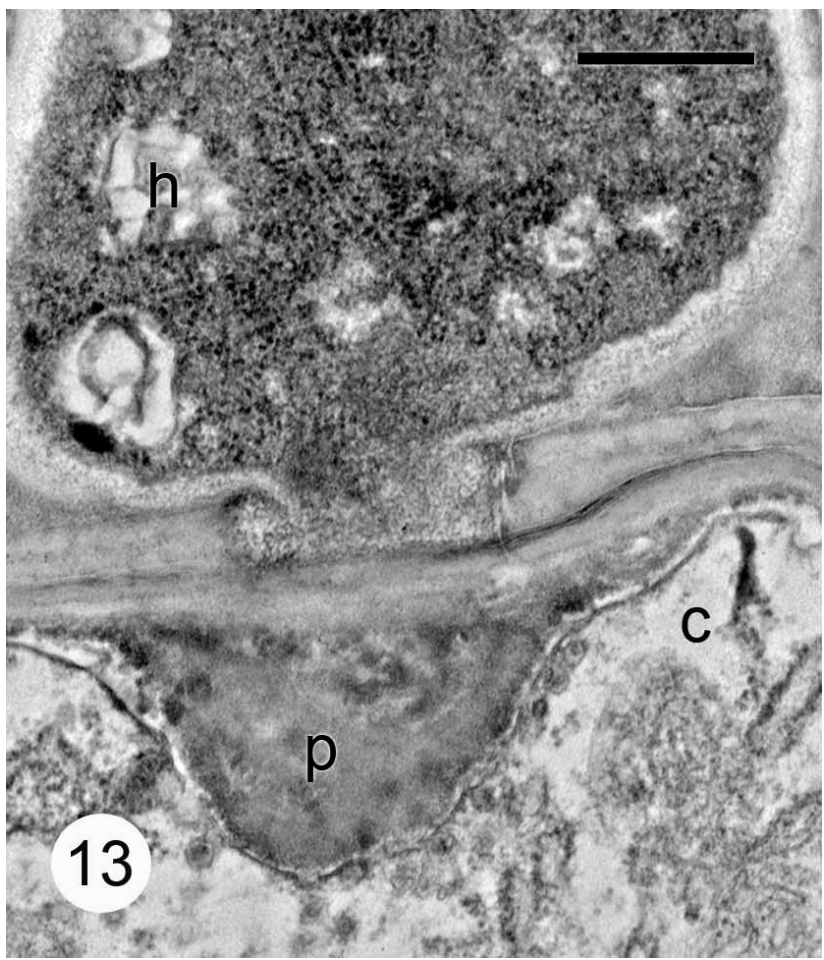

sections with $10 \% \mathrm{H}_{2} \mathrm{O}_{2}$ and subsequent incubation in blocking solution containing $1 \%$ bovine serum albumin acetylated (BSA-C) in TBS for $20 \mathrm{~min}$. Next, sections were treated with the primary antibody diluted at 1:100 in blocking solution for $2 \mathrm{~h}$ at room temperature. After washing six times in TBS, sections were treated with secondary antibodies (goat anti-rabbit IgG) coupled to $10 \mathrm{~nm}$ gold (Aurion, Wageningen, Netherlands) diluted at 1:20 in TBS. After rinsing with TBS followed by rinsing in distilled water, sections were stained with uranyl acetate and lead citrate. Specificity of the antibodies was assessed by testing the preimmune serum, the serum after immunisation and purification, and by incubation with the secondary antibody and omitting the primary antibody step.

\section{Results}

Hyphae growing out from mycelia cultivated on agar plugs proliferated on the agar surface and turned in the direction of roots up to $2 \mathrm{~mm}$ away (Fig. 1). Two days after inoculation, hyphae reached the root surface and produced a netlike mycelium over the root epidermis. The majority of hyphae followed the surface furrows produced by anticlinal walls of epidermal cells and differentiated numerous short sessile hyphopodia (Fig. 2). Penetration into the root occurred from such hyphopodia or by hyphae, slightly swollen at the penetration site. There was no good evidence of cuticle dissolution (Fig. 3). Other hyphae pushed epidermal cells apart and squeezed through the cleft that may have resulted from hyphal tip pressure (Fig. 4). After penetration,

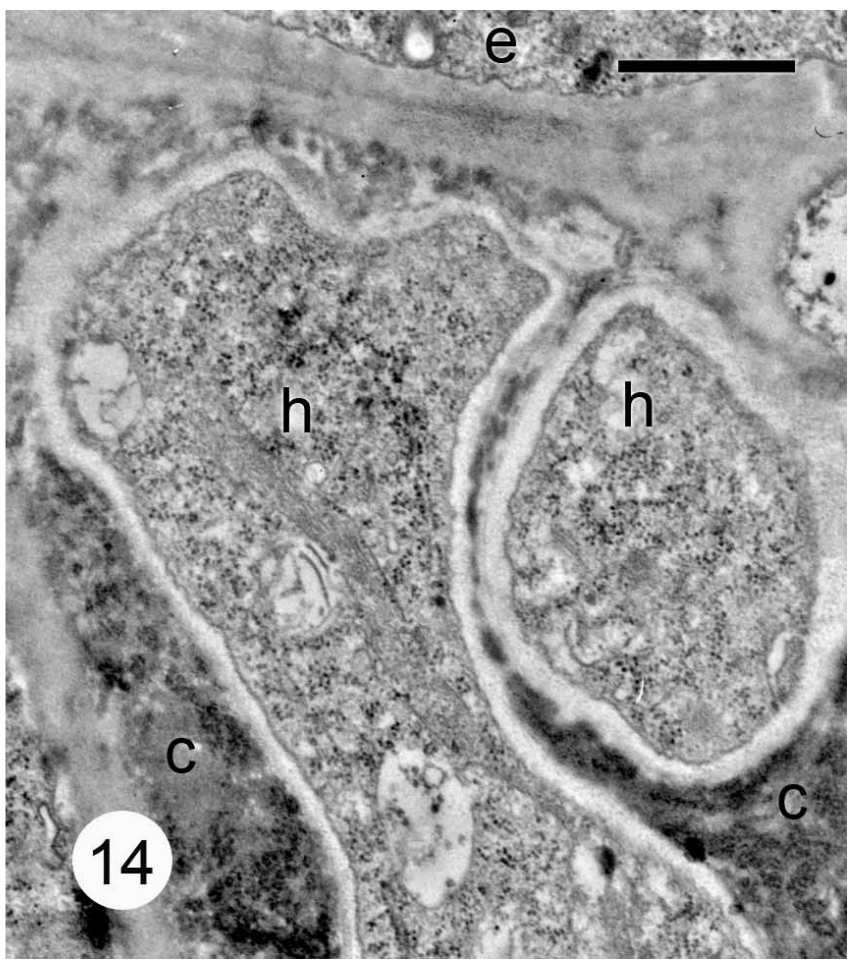

hyphae grew within the walls connecting epidermal and the first layer of cortical cells (Fig. 5).

As soon as hyphae started to grow between cortical cells, plant reactions were observed regularly along host walls close to hyphae. Two days after inoculation, such plant cells exhibited extensively undulated plasma membranes and some nearby vesicles were filled with lightly staining material (Fig. 6). Three days after inoculation, electron dense material accumulated within $<30 \%$ of these vesicles (Fig. 7). At $4 \mathrm{~d}$ after inoculation and later, prominent wall appositions were seen in all cortical cells close to hyphae. Finger-like projections of these wall appositions reached deep into the plant cytoplasm (Fig. 8). No hyphae were observed to grow deeper into the tissue.

To detect fungal excretions possibly responsible for the host responses noted above, antibodies were raised against mycelia of Stagonospora. These antibodies, detected with gold-tagged secondary antibodies, labelled the fungal wall, and the fungal cytoplasm including the organelles. In addition, gold label was found regularly within the plant cell walls (Fig. 9). Some gold particles were observed close to the plant plasma membrane and up to three very small vesicles were labelled in each section studied (Fig. 10). These vesicles were situated within the host cytoplasm, close to the plasma membrane. In the control sections incubated with the preimmune serum, neither plant nor fungal structures were labelled (Fig. 11). After immunization, sections of root epidermal cells incubated with the purified serum did not label any constituents of the plant cell above background (Fig. 12). 
Some hyphae growing within the host wall started to penetrate into the cortical cells (Fig. 13). These host cells produced prominent papillae (Fig. 13). We examined serial sections of 6 papillae out of 18 found. In these six cases, penetration by Stagonospora sp. strain 4/99-1 were blocked and the plant cells remained alive as indicated by the presence of an apparently intact plasmalemma (Fig. 13).

On rare occasions, we found single cortical cells with degenerated contents that had been invaded by hyphae (Fig. 14). Such hyphae exhibited organized organelles, but remained restricted to that cell and never were observed to grow deeper into the tissue.

\section{Discussion}

Endophytic fungi can perform important functions for the competitiveness of their hosts within the environment. The most important roles are protection from herbivory (Schardl and Phillips 1997) or from disease (Arnold et al. 2003). Other examples include increased thermotolerance for plants growing in geothermal soils (Redman et al. 2002), survival in competitive plant communities (Clay and Holah 1999), and enhanced plant growth under limited nutrient supply (Ernst et al. 2003; Schardl et al. 2004; Schulz and Boyle 2005). Ortiz-Garcia et al. (2003) demonstrated that Lophodermium comprises both needle cast pathogens and asymptomatic endophytes. In Picea, pathogenic species occupy derived positions in the pine clade and it is suggested that pathogenicity has evolved from endophytism.

This study with Stagonospora describes the behaviour of fungal hyphae on and within plant root tissue in a beneficial combination. The reaction of host cells to hyphae helps to characterize the quality of the interaction. On agar, hyphae of Stagonospora sp. strain 4/99-1 grew in the direction of the root and along the anticlinal walls of the root epidermis. These observations suggest a recognition of root exudates and thigmotropic responses on the epidermis. More experiments are needed to characterize the role of plant exudates. Replicas of root surfaces might elucidate a possible thigmotropic response similar to what has been observed with several plant pathogens (Staples and Hoch 1997).

Penetration events of the root epidermis by Stagonospora included undifferentiated hyphae, hyphopodia (Walker 1980), or hyphae pushing epidermal cells apart. This mode of penetration is very similar to that reported for Fusarium spp. pathogenic in many different plants. For example Fusarium oxysporum f.sp. lilii preferably penetrates anticlinal walls (Baayen and Rijkenberg 1999) while F. oxysporum f.sp. lini and $F$. oxysporum f.sp. vasinfectum penetrate both anticlinal walls and epidermal cells (Rodriguez-Gálvez and Mendgen 1995b; Kroes et al. 1998). Also Microdochium bolleyi, a fungus with beneficial effects to plants penetrates the epidermis of both reed and Hordeum vulgare (barley) roots in a similar way (Hemens et al. 1992; Damm et al. 2003). The observation that barely differentiated hyphae penetrate anticlinal epidermal walls or push epidermal walls apart suggests that different mechanisms of penetration cooperate. A combination of mechanical forces and enzymatic activities is known to contribute to the success of plant pathogenic infection (Wirsel et al. 2004).

However, further development of hyphae within the host tissue differs for parasites and endophytes. Root pathogens such as Bipolaris sorokiniana can reach the endodermis of Triticum aestivum (wheat) or barley roots within 2-3 d (Carlson et al. 1991). The wilt-inducing pathogenic F. oxysporum massively invades all tissues of Pisum sativum (pea) roots until it reaches the xylem. Considerable cytoplasmic disorganization of plant cells occurs in infected cells (Beckmann 1987; Benhamou and Garand 2001). In contrast, a nonpathogenic strain, $F$. oxysporum Fo 47, initially penetrates and colonizes the pea root in a way similar to the wild type, but hyphae never reach the stele. Fungal growth is restricted to the outermost root layers and only hyphae penetrating deeper into the cortex exhibit disorganized cytoplasmic contents (Benhamou and Garand 2001). Also, hyphae of the beneficial fungus $M$. bolleyi remain restricted to the outer cortex of the barley root in aerated soils (Hemens et al. 1992). In reed roots, under low oxygen conditions, this fungus invades epidermal cells only. In both examples, necrotic cells are not observed (Hemens et al. 1992; Damm et al. 2003). These results suggest that at least some endophytic fungi remain restricted to a certain type of plant tissue and grow in a biotrophic interaction.

It appears that Stagonospora sp. strain 4/99-1 is especially adapted to grow between the walls of the epidermis and the outermost layer of the root cortex. During subsequent development, only single hyphae reach the stem and the leaves of the plant (Ernst et al. 2003). Several defense reactions of the host seem to contribute to this restriction. Attempts of most hyphae to penetrate into the host cell were blocked by papillae. If single hyphae managed to penetrate cortical cells, the cell content becomes disorganized, similar to the hypersensitive response of plants in biotrophic and hemibiotrophic interactions in an incompatible situation. Host cell necrosis is thought to restrict further growth of hyphae (Richael and Gilchrist 1999; Hoeberichts and Woltering 2002). In addition, abundant wall appositions in host cells close to hyphae growing nearby indicate that Stagonospora sp. strain 4/99-1 elicits more defense reactions than some Neotyphodium species, which proliferate in leaves without any recognizable response of host cells (Christensen et al. 2002; Schardl et al. 2004). The wall appositions observed as soon as the fungus penetrated into the cortex of reed are very similar to wall appositions observed in Gossypium hirsutum (cotton) roots after infection with $F$. oxysporum f.sp. vasinfectum. They include many plant components produced during normal cell wall synthesis, but are very much enriched by callose. These wall appositions are the result of secretory events (Rodriguez-Gálvez and Mendgen 1995a). In ectomycorrhizae wall appositions may be produced during the development of plectenchyma of hyphae around cortical cells. These appositions are electron translucent and seem to support nutrient uptake by the fungus (Kottke and Oberwinkler 1986; Massicotte et al. 1986; Kottke 1997). This may not represent a typical defense reaction. Cytochemical studies designed to characterize the different types of wall appositions in root cells are needed to understand possible functions in each host-fungus interaction, especially in their role to inhibit fungal proliferation.

Our immunological studies with antibodies raised against Stagonospora sp. strain 4/99-1 showed that fungal material, most probably (glyco)-proteins or other wall constituents of 
the fungus, were secreted into the apoplast by hyphae. We found that secreted fungal molecules reached the plasmalemma and labelled vesicles turned up within the host cytoplasm. Many fungal molecules, such as oligosaccharides, glycopeptides, and peptides, are known to be secreted during infection by plant pathogens (Tenberge et al. 1999). They are targeted to specific high-affinity binding sites of host plant membranes (Hahn 1996). After binding to these receptors, plant defense reactions are elicited (Umemoto et al. 1997; Gomez-Gomez and Boller 2002). Endocytosis of receptors together with their ligands may occur as it has already been observed in Vicia faba after infection with Uromyces vignae (Xu and Mendgen 1997). These results and our experiments suggest that pathogenic and beneficial fungi share similarities in their interaction with the host plant.

We conclude that the endophytic lifestyle of Stagonospora is characterized by a restricted, balanced growth of hyphae in defined areas of plant tissue such as the epidermis. This equilibrium seems to be maintained by the highly regulated growth between epidermal cells on one hand and, on the other hand, appropriate defense-reactions of the host as soon as hyphae enter the cortex.

\section{Acknowledgements:}

This project was supported by the Deutsche Forschungsgemeinschaft, Sonderforschungsbereich 454 "Bodenseelitoral". The first author is grateful to the China Scholarship Council (CSC) for a scholarship. The authors thank Heinz Vahlenkamp, Eric Kemen, Michael Ernst, and Christine Giele for technical support in the course of the experiments. We also thank Dr. Jan Nechwatal, Dr. Stefan G. R. Wirsel, and Karin Neubert for critically reading the manuscript, and Dr. Ralf Voegele for help with the preparation of the antibodies. We acknowledge the constructive criticism of two anonymous reviewers.

\section{References}

Arnold, A.E., Mejia, L.C., Kyllo, D., Rojas, E.I., Maynard, Z., Robbins, N., and Herre, E.A. 2003. Fungal endophytes limit pathogen damage in a tropical tree. Proc. Natl. Acad. Sci. U.S.A. 100: 15649-15654. doi:10.1073/pnas.2533483100. PMID: 14671327.

Baayen, R.P., and Rijkenberg, F.H.J. 1999. Fine structure of the early interaction of lily roots with Fusarium oxysporum f.sp. lilii. Eur. J. Plant Pathol. 105: 431-443. doi:10.1023/ A:1008749514517.

Beckmann, C.H. 1987. The nature of wilt diseases of plants. American Phytopathological Society, St. Paul, Minn.

Benhamou, N., and Garand, C. 2001. Cytological analysis of defense-related mechanisms induced in pea root tissues in response to colonization by nonpathogenic Fusarium oxysporum Fo47. Phytopathology, 91: 730-740.

Cabral, D., Stone, J.K., and Carroll, G.C. 1993. The internal mycobiota of Juncus spp.: microscopic and cultural observations of infection patterns. Mycol. Res. 97: 367-376.

Carlson, H., Stenram, U., Gustafsson, M., and Jansson, H.-B. 1991. Electron microscopy of barley root infection by the fungal pathogens Bipolaris sorokiniana. Can. J. Bot. 69: 2724-2730.

Christensen, M.J., Bennett, R.J., and Schmid, J. 2002. Growth of Epichloe/Neotyphodium and p-endophytes in leaves of Lolium and Festuca grasses. Mycol. Res. 106: 93-106. doi:10.1017/ S095375620100510X.

Clay, K., and Holah, J. 1999. Fungal endophyte symbiosis and plant diversity in successional fields. Science, 285: 1742-1744. doi:10.1126/science.285.5434.1742. PMID: 10481011.

Damm, U., Brune, A., and Mendgen, K. 2003. In vivo observation of conidial germination at the oxic-anoxic interface and infection of submerged reed roots by Microdochium bolleyi. FEMS Microbiol. Ecol. 45: 293-299.

Ernst, M., Mendgen, K.W., and Wirsel, S.G.R. 2003. Endophytic fungal mutualists: Seed-borne Stagonospora spp. enhance reed biomass production in axenic microcosms. Mol. Plant-Microbe Interact. 16: 580-587. PMID: 12848423.

Gomez-Gomez, L., and Boller, T. 2002. Flagellin perception: a paradigm for innate immunity. Trends Plant Sci. 7: 251-256. PMID: 12049921.

Hahn, M.G. 1996. Microbial elicitors and their receptors in plants. Annu. Rev. Phytopathol. 34: 387-412. doi:10.1146/annurev. phyto.34.1.387. PMID: 15012549.

Hemens, E., Steiner, U., Schoenbeck, F.S. 1992. Infektionsstrukturen von Microdochium bolleyi an Wurzeln und Koleoptilen von Gerste. J. Phytopathol. 136: 57-66.

Hoeberichts, F.A., and Woltering, E.J. 2002. Multiple mediators of plant programmed cell death: interplay of conserved cell death mechanisms and plant specific regulators. Bioassays, 25: $47-57$.

Jumpponen, A., and Trappe, J.M. 1998. Dark septate endophytes: a review of facultative biotrophic root-colonizing fungi. New Phytol. 140: 295-310. doi:10.1046/j.1469-8137.1998.00265.x.

Kottke, I. 1997. Fungal adhesion pad formation and penetration of root cuticle in early stage mycorrhizas of Picea abies and Laccaria amethystea. Protoplasma, 196: 55-64. doi:10.1007/ BF01281058.

Kottke, I., and Oberwinkler, F. 1986. Mycorrhiza of forest trees structure and function. Trees (Berlin), 1: 1-24.

Kroes, G.M.L.W., Baayen, R.P., and Lange, W. 1998. Histology of root rot of flax seedlings (Linum usitatissimum) infected by $\mathrm{Fu}$ sarium oxysporum f.sp. lini. Eur. J. Plant Pathol. 104: 725-736. doi:10.1023/A:1008604417614.

Latch, G.C.M., and Christensen, M.J. 1985. Artificial infection of grasses with endophytes. Ann. Appl. Biol. 107: 17-24.

Massicotte, H.B., Peterson, R.L., Ackerley, C.A., and Piché, Y. 1986. Structure and ontogeny of Alnus crispa - Alpova diplophloeus ectomycorrhizae. Can. J. Bot. 64: 177-192.

Murashinge, T., and Skoog, F. 1962. A revised medium for rapid growth and bioassays with tobacco tissue cultures. Physiol. Plant. 15: 473-497.

Ortiz-Garcia, S., Gernandt, D.S., Stone, J.K., Johnston, P.R., Chapela, I.H., Salas-Lizana, R., and Alvarez-Buylla, E.R. 2003. Phylogenetics of Lophodermium from pine. Mycologia, 95: 846-859.

Redman, R.S., Scheehan, K.B., Stout, R.G., Rodriguez, R.J., and Henson, J.M. 2002. Thermotolerance generated by plant/fungal symbiosis. Science, 298: 1581. doi:10.1126/science.1072191. PMID: 12446900.

Richael, C., and Gilchrist, D. 1999. The hypersensitive response: A case of hold or fold? Physiol. Mol. Plant Pathol. 55: 5-12. doi:10.1006/pmpp.1999.0209.

Rodriguez-Gálvez, E., and Mendgen, K. 1995a. Cell wall synthesis in cotton roots after infection with Fusarium oxysporum. The deposition of callose, arabinogalactans, xyloglucans, and pectic components into walls, wall appositions, cell plates and plasmodesmata. Planta, 197: 535-545. PMID: 8580765.

Rodriguez-Gálvez, E., and Mendgen, K. 1995b. The infection pro- 
cess of Fusarium oxysporum in cotton root tips. Protoplasma, 189: $61-72$.

Schardl, C.L., and Phillips, T.D. 1997. Protective grass endophytes: Where are they from and where are they going? Plant Dis. 81: 430-438.

Schardl, C.L., Leuchtmann, A., and Spiering, M.J. 2004. Symbioses of grasses with seedborne fungal endophytes. Annu. Rev. Plant Biol. 55: 315-340. doi:10.1146/annurev.arplant.55.031903. 141735. PMID: 15377223.

Schulz, B., and Boyle, C. 2005. The endophytic continuum. Mycol. Res. 109: 661-686. doi:10.1017/S095375620500273X. PMID: 16080390.

Seifers, D., and Ammon, V. 1980. Mode of penetration of sycamore leaves by Gloeosporium platani. Phytopathology, 70: 1050-1055.

Staples, R.C., and Hoch, H.C. 1997. Physical and chemical cues for spore germination and appressorium formation by fungal pathogens. In The Mycota V. Part A. Edited by G.C. Carroll and P. Tudzynski. Springer-Verlag, Berlin. pp. 27-40.

Stone, J.K. 1988. Fine structure of latent infections by Rhabdocline parkeri on Douglas-fir, with observations on unifected epidermal cells. Can. J. Bot. 66: 45-54.

Tenberge, K.B., Brockmann, B., and Tudzynski, P. 1999. Immunogold localization of an extracellular $\beta$-1,3-glucanase of the ergot fungus Claviceps purpurea during infection of rye. Mycol. Res. 103: 1103-1118. doi:10.1017/S095375629800820X.

Tucker, S.L., and Talbot, N.J. 2001. Surface attachment and prepenetration stage development by plant pathogenic fungi. Annu. Rev. Phytopathol. 39: 385-417. doi:10.1146/annurev.phyto.39.1. 385. PMID: 11701871.

Umemoto, N., Kakitani, M., Iwamatsu, A., Yoshikawa, M., Yamaoka, N., and Ishida, I. 1997. The structure and function of a soybean $\beta$-glucan-elicitor-binding protein. Proc. Natl. Acad. Sci. U.S.A. 94: 1029-1034. doi:10.1073/pnas.94.3.1029. PMID: 9023377.

Viret, O., and Petrini, O. 1994. Colonization of beech leaves (Fagus sylvatica) by the endophyte Discula umbrinella (teleomorph: Apiognomonia errabunda. Mycol. Res. 98: 423-432.

Walker, J. 1980. Gaeumannomyces, Linocorpon, Ophiobolus and several other genera of scolecospored ascomycetes and Phialophora conidial states, with a note on hyphopodia. Mycotaxon, 11: $1-129$.

Wirsel, S.G.R., Reimann, S., and Deising, H.B. 2004. Genetics of Phytopathology: Fungal morphogenesis and plant infection. Prog. Bot. 65: 147-178.

Xu, H., and Mendgen, K. 1997. Targeted cell wall degradation at the penetration site of cowpea rust basidiosporelings. Mol. Plant Microbe Interact. 10: 87-94. 